\title{
Melanin Synthesis Inhibitory Effect of Eriobotryae Folium Extracts \& Eriobotryae Folium and Phreatic Water Mixture
}

\author{
Jae-Song Choi ${ }^{1}$, Jung-Hwan Park ${ }^{2}$, Young-Mee $\mathrm{Koh}^{2}$, Jin-young Kwak ${ }^{2}$, Taek-Won $\mathrm{Ahn}^{2}$ \\ ${ }^{1}$ Dept. of Sasang Constitutional Medicine, College of Oriental Medicine, Daejeon University \\ ${ }^{2}$ Department of Sasang Constitutional Medicine, Cheonan Oriental Medicine Hospital of Daejeon University
}

\begin{abstract}
Objectives: As interests in the beauty of skin is growing continuously, more people are focusing on white and clean skin. Melanin is the major factor that determines skin color. The abnormal concentration of melanin causes various skin diseases such as vitiligo, freckles, and melasma. This study investigated the inhibitory effect of Eriobotryae Folium extracts $(\mathrm{EF})$ with phreatic water $(\mathrm{PW})$ on the melanin synthesis.

Methods: The effect of EF on melanin synthesis was evaluated by using mouse melanoma cells (B16F10). To define the mechanisms, real-time PCR and western blot were used. We also evaluated the inhibitory effects of EF and PW on melanin synthesis by using HRM-2 melanin-possessing hairless mice. After UVB irradiation, melanin differences between the skin parts that were treated and untreated with EF and PW. Levels of mRNA were measured by real-time quantitative PCR and histological analysis of the dorsal skin was conducted by hematoxylin and eosin staining. Results: EF inhibited various mechanisms of melanogenesis, and the effect was increased when combined with PW. In vitro experiments have shown that EF inhibited the expressions of tyrosinase related protein-1 (TRP-1) mRNA, tyrosinase mRNA, microphthalmia-associated transcription factor (MITF) mRNA and the tyrosinase inhibitory activation, but it stimulated the extracellular regulated kinase (ERK) mRNA expression. In vivo experiments have shown that EF prevented melanogenesis in the mice dorsal skin and inhibited TRP-1 mRNA expression. Also these effects were increased when combined with PW.

Conclusions: $\mathrm{EF}$ and $\mathrm{PW}$ might be a new and effective treatment for whitening and treating pigmentation of skin.
\end{abstract}

$\overline{K e y}$ Words : Eriobotryae Folium, Melanin synthesis, Phreatic water, Whitening effect

\section{Introduction}

Recently, ultraviolet exposure to skin is increased due to environmental pollution. So skin aging, pigmentation and wrinkles have become serious problems. Also as the development of society, interest in the beauty of the skin is growing continuously $[1,2]$.

The color of human skin is determined by the amount of melanin, carotene, and hemoglobin. Among them, melanin is the most important factor. If melanin is produced abnormally low, skin lesions such as vitiligo are caused. Conversely, if it is overproduced, it forms the freckles, melasma, and it

Skin pigmentation such as freckles and melasma is also closely associated with skin cancer $[3,4]$ is mainly due to the increase of melanin synthesis by the melanocytes. Therefore, by inhibiting melanin

\footnotetext{
- Received : 6 December 2017

- Revised : 22 December 2017

- Accepted : 22 December 2017

- Correspondence to: Taek-Won Ahn

Department of Sasang Constitutional Medicine, Cheonan Oriental Medicine Hospital of Daejeon University 4, Notaesan-ro, Seobuk-gu, Cheonan-si, Chungcheongnam-do, Republic of Korea. 331-958

Tel : +82-41-521-7538, Fax : +82-41-521-7007, E-mail : twahn@dju.kr
} 
synthesis, it is possible to expect the effect of skin whitening [5].

In recent researches, interests in effective and stable natural extracts that have the skin whitening effect is growing continuously. Numerous researches are focusing particularly on herbal medicine, which efficacy and safety have been proven from long time usage [6].

Eriobotryae Folium (EF) is the dried leaf of loquat tree which belongs to the Rosaceae and it has antioxidant, anti-inflammatory effect. Many experiments are undergoing for the development of functional cosmetics utilizing EF [7]. However, these researches are mostly about remedying wrinkles through antioxidant effects or remedying skin inflammation through anti-inflammatory effects. Researches dealing with the skin whitening effect of EF are in shortage.

Thus, in this research we investigated the whitening effect of EF by inhibiting melanin production. Additionally we proved that the effect increases when $\mathrm{EF}$ was used with hot spring water.

\section{Methods}

\section{Cell strain and cell culture}

B16F10 mouse melanoma cells (ATCC, Manassas, VA, USA) were used as cell strain in experiments. The cells were floated on Dulbecco's modified Eagle medium(DMEM), to which $10 \%$ fetal bovine serum (FBS) and $1 \%$ penicillin/streptomycin $(100 \mathrm{U} / \mathrm{ml})$ were added, and adapted in the $37^{\circ} \mathrm{C}, 5 \%, \mathrm{CO}_{2}$ incubator for subculture.

\section{Medicines}

The Eriobotryae Folium(EF) was purchased from Omniherb (www.omniherb.com), Daegu, Korea. Its place of origin is China.

\section{Separation of Eriobotryae Folium (EF) extracts}

$200 \mathrm{~g}$ EF powder was digested in 30\% ethanol (1.51) in ASE300 Accelerated Solvent Extractor (DIONEX Co., Sunnyvale, CA, USA) for 3 days, and the liquid was extracted for 20 minutes in $50^{\circ} \mathrm{C}$. $18 \mathrm{~g}$ of extract was obtained by lyophilizing extracted remaining solution that was obtained by decompressing drying extracted solution in cold trap $-70^{\circ} \mathrm{C}$ and chamber temperature $40^{\circ} \mathrm{C}$ in freezing dryer (Biotron Co., Bucheon, Geonggi, Korea) for 24 hours.

\section{Animals}

Total 6 ( $\mathrm{n}=6$ ) 20-22g HRM-2 melanin-possessing hairless mice from Hoshino Laboratory Animals Co. Ltd. (Saitama, Japan) were used. They were fed with antibiotic-free pellet feed (Samyang Feed Co., Seoul, Korea) and water. They were adapted in the vivarium for one week that maintains temperature $22 \pm 2^{\circ} \mathrm{C}$, humidity $55 \pm 15 \%$ with 12 hours light-dark cycle.

This experiment was approved by the Institutional Animal Care and Use Committee of Daejeon University (approval number: DJUARB2012-019) for ethical and scientific validity of animal experiment and efficient management.

\section{Phreatic Water (PW)}

The water was collected from Paradise Spa Dogo, Korea. The component analysis of the PW of DOGO had been conducted in the research of researcher Jang [8], and drinking water test was investigated by Chungnam Institute of Health and Environment, Korea.

\section{Sunblock Cream}

The sunblock cream was purchased from Medi Spa Sunblock SPF 47/PA $70 \mathrm{ml}$ (HUNUSBIO, INC, Korea) from medical-skincare.co.uk. 


\section{Reagent and Equipment}

Experimental drugs used to measure whitening effect were tyrosinase mushroom, dimethyl sulfoxide (DMSO) and levo-3, 4-dihydroxyphenylalanine (L-DOPA) purchased from Sigma Chemical Co. (St. Louis, MO, USA). Those used for polymerase chain reaction (PCR) were extracellular regulated kinase (ERK), cAMP resposive element binding protein (CREB), microphthalmia associated transcription factor (MITF), tyrosinase, tyrosinase related protein 1 (TRP-1), tyrosinase related protein 2 (TRP-2), glyceraldehyde-3-phosphate dehydrogenase (GAPDH), primary antibody and secondary antibodies such as mouse-antigoat and rabbit-antimouse purchased from Santa Cruz Biotechnology (Santa Cruz, CA, USA).

For cell culture, Dulbecco's modified Eagle medium (DMEM), fetal bovine serum (FBS), phosphate buffered saline (PBS), penicillin/streptomycin, and trypsin were purchased from Thermo Scientific Hyclone (Logan, UT, USA) and Gibco BRL Co. (Grand Island, NY, USA). For cytototoxicity measurement, a haemacytometer (Marienfeld-Superior, Germany) and 3-[4,5-dimethylthiazol]-2-yl]-2,5-diphenyl -tetrazoliumbromide (MTT) were purchased from Sigma Chemical Co.. For the HPLC reference sample, the Luteolin product was purchased from Sigma Chemical Co.. For other experimental drugs, first-class experimental drugs were used.

The EF analysis HPLC(Waters 2695 system; Waters Co., Milford, Mam USA) was the Agilent 1200 series, and the autosampler, the column oven, the binary pump, the DAD detector (Agilent Techonologies, Santa Clara, CA, USA), and the degasser (Agilent Technologies, Santa Clara, CA, USA) were used. The software used was Chemstation software (Agilent Technologies, Santa Clara, CA, USA).

Instruments used in this experiment includes the hot water extractor (DWT-1800T, Daewoong, Seoul, Korea), the reduced pressure distiller (EYELA, Tokyo,
Japan / BUCHI B-480, Flawil, Switzerland), the centrifuge (Hanil Science Industrial, Incheon, Korea), the freeze dryer (Ilshin biobase Co., Dongduchun, Gyeonggi, Korea / EYELA FDU-540, Tokyo, Japan), the microscope (Olympus, Tokyo, Japan), the $\mathrm{CO}_{2}$ incubator (Vision Scientific, Daejeon, Korea), the vortex (Scientific Industries, INC., Bohemia, NY, USA), the $\mathrm{pH}$ meter (Mettler-Toledo AG, Greifensee, Switzerland), the BOD incubator (Daihan Scientific, Wonju, Gangwon, Korea), the autoclave (JS Research Inc., Gongju, Chungnam, Korea), the ELISA reader (Tecan, Mannedorf, Switzerland), the PCR (C-100, Bio-Rad Laboratories, Hercules, CA, USA), the plate shaker (Lab-Line, San Diego, CA, USA), the spectrophotometer (Shimazu, Kyoto, Japan), the biofreezer (Sanyo Electric Co., Osaka, Japan), the Applied Biosystems real time quantitative (RQ) PCR (Life Technologies, Grand Island, NY, USA), and the HPLC (Waters Co., Milford, MA, USA).

\section{Manufacturing Cream of EF Extracts}

The cream was made by combining water, oil, and stabilizer. These creams was mixed with the each additives $2 \%$ EF extracts and distilled water (DW) mixture or $2 \% \mathrm{EF}$ extracts phreatic water (PW) or $0.5 \%$ SPF $47 / \mathrm{PA}^{++}$). The procedure of manufacture is as follows: after the water phase and oil phase materials were melted in main mixer and side mixer respectively in the temperature of about $70^{\circ} \mathrm{C}$, the solutions were put into both mixers and the homo mixer was operated for 20 minutes. When it reached the emulsion state, the temperature was lowered to under $40^{\circ} \mathrm{C}$ and temperature-sensitive materials such as vitamins were put, and the $\mathrm{pH}$ was adjusted. Lastly the final stirring and 5-minute homo mixer was operated for 5 minutes, then it was filtered and filled(Table 1).

\section{HPLC Effective Component Analysis of $\mathrm{EF}$}


Table 1. EF Cream Formulation

\begin{tabular}{|c|c|c|c|c|}
\hline & & $\begin{array}{c}2 \% \text { EF \& } \\
\text { DW cream }\end{array}$ & $\begin{array}{l}2 \% \text { EF \& } \\
\text { PW cream }\end{array}$ & $\begin{array}{c}0.5 \% \mathrm{SPF} \\
47 / \mathrm{PA}++ \text { cream }\end{array}$ \\
\hline Phase & Chemical name & & Contents $(\%)$ & \\
\hline \multirow{6}{*}{ Water } & Glycerine & 10.00 & 10.00 & 10.00 \\
\hline & Silicon derivatives & 0.20 & 0.20 & 0.20 \\
\hline & Microcide-C & 0.20 & 0.20 & 0.20 \\
\hline & EDTA-2Na & 0.01 & 0.01 & 0.01 \\
\hline & Keltrol F (1 \%) & 5.00 & 5.00 & 5.00 \\
\hline & Sepiplus 400 & 0.30 & 0.30 & 0.30 \\
\hline \multirow{10}{*}{ Oil } & Lanette $\mathrm{O}$ & 2.00 & 2.00 & 2.00 \\
\hline & Olive M 1000 & 1.00 & 1.00 & 1.00 \\
\hline & Tego care 450 & 2.00 & 2.00 & 2.00 \\
\hline & Puresyn 4 & 2.00 & 2.00 & 2.00 \\
\hline & TCG-M & 3.00 & 8.00 & 8.00 \\
\hline & DC $200 / 6 \mathrm{cs}$ & 2.50 & 2.50 & 2.50 \\
\hline & Lipex Shea & 1.00 & 1.00 & 1.00 \\
\hline & Vitamin $\mathrm{E}$ & 0.50 & 0.50 & 0.50 \\
\hline & D-P & 0.10 & 0.10 & 0.10 \\
\hline & BHT & 0.02 & 0.02 & 0.02 \\
\hline \multirow{2}{*}{ Stabilizer } & DW & 2.00 & & \\
\hline & PW & & 2.00 & \\
\hline \multirow{4}{*}{ Additives } & $2 \% \mathrm{EF}+\mathrm{DW}$ & 2.00 & & \\
\hline & $2 \% \mathrm{EF}+\mathrm{PW}$ & & 2.00 & \\
\hline & $0.5 \%$ SPF $47 / \mathrm{PA}^{++}$ & & & 0.5 \\
\hline & Total & 100 & 100 & \\
\hline
\end{tabular}

The oven was conditioned at $25^{\circ} \mathrm{C}, 348 \mathrm{~nm}$ wavelength, and $1.0 \mathrm{ml} / \mathrm{min}$ flow rate for HPLC. The column used was the Luna C18 column $(250 \mathrm{~mm} \times$ 4.6mm: particle size 5um; Phenomenex, Torrance, CA, USA). $0.1 \%$ formic acid was added to $100 \%$ third DW(Solvent A), and 100\% acetonitrile(Solvent B). Solvent gradient eluents for solvents are as shown in Table 2. Chlorogenic acid and isoquercitrin were used as the index component, and components of the reference sample and EF were analyzed.

\section{Effects of EF on melanin synthesis in melanoma cells (in vitro)}

1) Cytotoxicity measurement by MTT assay

The cytotoxicity was measured by the Carmichael method [9]. A total of $0.18 \mathrm{ml}$ of B16F10 cells was separately seeded in the 96 well plate by $5 \times 10^{4}$ cells
Table 2. Solvent Gradient Condition for HPLC-DAD

\begin{tabular}{cccc}
\hline Final time $(\mathrm{min})$ & Flow rate $(\mathrm{m} \ell / \mathrm{min})$ & A & B \\
\hline 0 & 0.3 & 85 & 15 \\
10 & 0.3 & 80 & 20 \\
30 & 0.3 & 65 & 35 \\
35 & 0.3 & 65 & 35 \\
40 & 0.3 & 85 & 15 \\
\hline
\end{tabular}

A : Water with $0.1 \%$ formic acid.

B : Acetonitrile with $0.1 \%$ formic acid.

per well. Samples were prepared by concentrations, and $0.02 \mathrm{ml}$ of each sample was added into each well and the plate was placed and cultured in the $5 \% \mathrm{CO}_{2}$ incubator for 24 hours. The control group was added with the same amount of DW as the sample group, and was cultured under the identical conditions. The MTT solution prepared in the $5 \mathrm{mg} / \mathrm{ml}$ concentration was added at $0.02 \mathrm{ml}$ each, and the both groups were 
cultured for 4 hours. Then $0.15 \mathrm{ml}$ of dimenthyl sulfoxide was added to each for 30 minutes reaction. The optical absorbance was measured at $540 \mathrm{~nm}$ by the ELSA reader. The cytotoxicity was indicated by the optical absorbance reduction ratio of the indication solution added and non-added group.

Cytotoxicity $(\%)=(1-$ Absorbance of the sample added group/ Absorbance of the non added group) $\mathrm{x}$ 100

2) Tyrosinase inhibitory activity measurement of $\mathrm{EF}$

The tyrosinase inhibitory activity was measured in accordance with the Yagi method [10]. In the

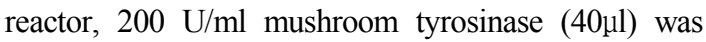

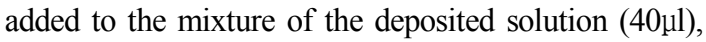
in which $10 \mathrm{mM}$ L-DOPA was dissolved over 67 $\mathrm{mM}$ sodium phosphate buffer( $\mathrm{pH} 6.8 ; 80 \mu \mathrm{l})$, and the sample solution $(40 \mu \mathrm{l})$. It was reacted for 10 minutes at $37^{\circ} \mathrm{C}$. The DOPA chrome generated in the reaction solution was measured at $492 \mathrm{~nm}$. The tyrosinase reaction solution was measured at $492 \mathrm{~nm}$. The tyrosinase inhibitory activity was indicated by the optical absorbance reduction ratio of the indication solution added group and the nonadded group.

Inhibitory ratio $(\%)=(1-$ Absorbance of the sample added group/ Absorbance of the non added group) $\mathrm{x}$ 100

3) B16F10 cell experimental group classification

To identify the effect of EF when inducing melanin synthesis on B16F10 cells, the normal group received no treatment, the negative control group received only a-MSH $(100 \mathrm{nM})$ treatment, the positive control group received a-MSH $(100 \mathrm{nM})$ and kojic acid $(50 \mathrm{ppm})$ treatment, and the experimental group received a-MSH $(100 \mathrm{nM})$ and EF extracts treatment $(5,25,50 \mu \mathrm{g} / \mathrm{m} \ell)$.
4) mRNA expression measurement by PCR

(1) Total RNA extraction and cDNA synthesis

B16F10 cells were seeded on the $100 \mathrm{~mm}$ culture dish and cultured for 24 hours. These were treated with a-MSH $(100 \mathrm{nM}), \mathrm{EF}(5,25,50 \mu \mathrm{g} / \mathrm{ml})$, and kojic acid (50 ppm) and cultured for 24 hours. Then, the culture medium was removed. The trizol lysis buffer was planted in each well by $1 \mathrm{ml}$ for cell lysis, chloroform $(200 \mathrm{ml})$ was added to each, and the dish was shaken up and down for 20 seconds. It was centrifuged for 20 minutes at 13,200 rpm. The supernatant was collected and mixed in the tube that contained isopropanol $(500 \mathrm{ml})$. Then, it was centrifuged for 5 minutes at $13,200 \mathrm{rpm}$. The supernatant was removed then dried at room temperature. The DEPC was seeded in the 96-well plate by $50 \mu 1 /$ well and melted. RNA $(5 \mu \mathrm{g})$ and sterile water $(195 \mu l)$ were added in each well. Total RNA quantities were measured by measuring the optical absorbance at $260 \mathrm{~nm}$ and $280 \mathrm{~nm}$ respectively. Overall, $10 \mu \mathrm{l}$ was made with Oligo(dT) 15 primer $(500 \mu \mathrm{g} / \mathrm{ml}) \quad 1 \mu \mathrm{l}$, extracted RNA (2 $\mu \mathrm{g})$ and nuclease-free water. It was reacted for 5 minutes at $75^{\circ} \mathrm{C}$. Then, $5 \mathrm{X}$ reaction buffer, $\mathrm{MgCl}_{2}, \mathrm{PCR}$ necleotide mix, rnasin inhibitor, reverse transcriptase, and nuclease free water were added. It was reacted for 5 minutes at $25^{\circ} \mathrm{C}$, for 60 minutes at $42^{\circ} \mathrm{C}$, and for 15 minutes at $70^{\circ} \mathrm{C}$ to synthesized cDNA.

(2) Reverse transcription (RT) PCR

Go Flexi DNA polymerase, primer, and synthesized cDNA was added in the PCR tube and fully blended, and PCR was conducted. The primer sequence used in the experiment is listed in Table 3. The GAPDH was kept for 30 seconds at $94^{\circ} \mathrm{C}$, for 45 seconds at $55^{\circ} \mathrm{C}$, and for 45 seconds at $72^{\circ} \mathrm{C}$ for 35 times. The tyrosinase was kept for 30 seconds at $94^{\circ} \mathrm{C}$, for 45 seconds at $60^{\circ} \mathrm{C}$, and for 45 seconds at $72^{\circ} \mathrm{C}$ for 40 times. The TRP-1, TRP-2, and MITF were kept for 30 seconds at $94^{\circ} \mathrm{C}$, for 45 seconds at $58^{\circ} \mathrm{C}$, and for 45 seconds at $72^{\circ} \mathrm{C}$ for 40 times. The MMP-1 was 
Table 3. Primer Sequence (in B16F10 cell)

\begin{tabular}{|c|c|c|}
\hline Gene & Primer & Sequence $\left(5^{\prime} \rightarrow 3^{\prime}\right)$ \\
\hline \multirow{2}{*}{ MITF } & Forward & AGC GTG TAT TTT CCC CAC AG \\
\hline & Reverse & TAG CTC CTT AAT GCG GTC GT \\
\hline \multirow{2}{*}{ TRP-1 } & Forward & ACT TCA CTC AAG CCA ACT GC \\
\hline & Reverse & AGC TTC CCA TCA GAT GTC GT \\
\hline \multirow{2}{*}{ TRP-2 } & Forward & GCT CCA AGT GGC TGT AGA CC \\
\hline & Reverse & AAT GCA GTG GCT TGG AAA TC \\
\hline \multirow{2}{*}{ Tyrosinase } & Forward & GAC GGT CAC TGC ACA CTT TG \\
\hline & Reverse & GCC ATG ACC AGG ATG AC \\
\hline \multirow{2}{*}{ GAPDH } & sense & TGA AGG TCG GTG TGA ACG GAT TTG GC \\
\hline & anti-sense & CAT GTA GGC CAT GAG GTC CAC CAC \\
\hline \multirow{2}{*}{$\beta$-actin } & Forward & ATT GTT GCC ATC AAT GAC CC \\
\hline & Reverse & AGT AGA GGC AGG GAT GAT \\
\hline
\end{tabular}

kept for 30 seconds at $94^{\circ} \mathrm{C}$, for 60 seconds at $56^{\circ} \mathrm{C}$, for 1 minute at $72^{\circ} \mathrm{C}$ for 35 times. After synthesis by PCR, it was treated with electrophoresis fir 49 minutes at $100 \mathrm{~V}$ in $1.5 \%$ agarose gel added with $0.002 \%$ ethidium bromide. The LAS 4,000 instrument (GE Healthcare Bio Sciences AB, Uppsala, Sweden) was used to measure the band for quantitative analysis.

\section{5) Protein expression measurement by Western} blot

B16F10 cells were seeded on a $100-\mathrm{mm}$ culture dish and cultured for 24 hours. These were treated with a-MSH $(100 \mathrm{nM})$, EF $(5,25,50 \mu \mathrm{g} / \mathrm{ml})$, and kojic acid $(50 \mathrm{ppm})$ and cultured for 24-48 hours. Then the culture medium was removed. After washing twice with phosphate buffered saline, RIPA buffer $10 \mathrm{ml}$ added with the complete mini 1 tab was dissolved into 100 1 . Then, it was centrifuged for 20 minutes at $4^{\circ} \mathrm{C}, 12,000 \mathrm{rpm}$. The centrifuged supernatant was quantified by the Bradford assay, and $30 \mu \mathrm{l}$ protein was separated by electrophoresis (sodium dodecyl sulfate polyacrylamide gel electrophoresis) using $10 \%$ gel. The semidry transfer cell instrument (Hofer, Inc., San Francisco, CA, USA) was used to move the separated protein on the polyvinyl difluoride membrane(PVDF). Then, it was cultured in the blocking buffer $(5 \%$ skim milk in
Tris buffered saline with Tween) for 1 hour at room temperature. The primary antibody (PKA, $\beta$-actin) was diluted and kept overnight at $4^{\circ} \mathrm{C}$. It was washed using Tris buffered saline with Tween for three times at 10-minute intervals. The secondary antibody(anti rabbit, anti goat) was diluted by 1 : 1,000 , and cultured for 2 hours at room temperature. Then, it was washed for three times. The LAS 4000 instrument(GE Healthcare Bio Sciences AB, Uppsala, Sweden) was used to measure the band for quantitative analysis.

6) Statistical analysis

Every experiment was repeated three times to obtain the average and standard deviation values. SPSS version 10.0(Chicago, IL, USA) software was used to process the statistical results. For significant difference verification, significance was analyzed using Turkey/s honest significant difference test at a $=0.05$ level after analysis of variance $\left({ }^{*} p<0.05\right.$, $* * p<0.01, * * * p<0.001)$.

\section{Effect of EF with PW on melanin synthesis in HRM-2 melanin-possessing hairless mice(in vivo)}

Each HRM-2 mice were applied with specimen on the right dorsal skin, and the melanin synthesis was compared with the untreated left dorsal skin after 
UVB irradiation.

1) HRM-2 mice experimental group classification The experimental groups were classified as the following. The normal group was applied with the base ointment on the right dorsal skin. The negative control group was treated with the base ointment and UVB irradiation, and the positive control group was treated with $0.5 \%$ sunblock cream and UVB irradiation. The Experimental group 1 was treated with $\mathrm{EF}+\mathrm{DW}$ cream and UVB irradiation on the right upper side, and the experimental group 2 was treated with $\mathrm{EF}+\mathrm{PW}$ cream and UVB irradiation on the right lower side of dorsal skin.

2) UVB irradiation and hyperpigmentation induction

The UVB lamp (15 $\mathrm{W}$ type, UV maximum wave length $312 \mathrm{~nm}$; UV intensity $100 \mu \mathrm{W} \mathrm{cm}^{-2}$, Ieda Boeki Co., Tokyo, Japan) was used to irradiate UVB on the dorsal skins of 7-week-old HRM-2 mice to identify the effect of $2 \% \mathrm{EF}+\mathrm{DW}$ and $2 \% \mathrm{EF}+\mathrm{PW}$ on changes in skin thickness, elasticity, and pigmentation. The base ointment and each sample were blended into the form of cream $(0.5 \%$ sunblock cream, $2 \% \mathrm{EF}+\mathrm{DW}$ cream, $2 \% \mathrm{EF}+\mathrm{PW}$ cream). It was applied on the right dorsal skin of each HRM-2 mouse, and no treatment was made on the left dorsal skin. Each mouse was anesthetized and irradiated with UVB from a $30 \mathrm{~cm}$ distance for 5 minutes at a time. UVB was irradiated three times a week for 4 weeks. Based on studies on UVB using animal whitening experiments $[11,12]$, the experimental duration was configured for a total of 5 weeks.

\section{3) Visual pigmentation observation}

To visually observe the dorsal skin in which pigmentation was induced by UVB irradiation, applied parts of the solvent control group and the sample group were observed for three times on the $1^{\text {st }}, 3^{\text {rd }}, 5^{\text {th }}$ week after the experiment was launched to compare the colored skin states of experimental animals for whitening effect. Mice were etherized, and a digital camera (D 70 model; Nikon, Tokyo, Japan) was used to take pictures of skin surface states.

4) Software analysis on pigmented images

To analyze the images taken by the digital camera on the $1^{\text {st }}, 3^{\text {rd }}, 5^{\text {th }}$ week after the experiment started, the image analysis software (Bio-Rad, USA) was used. To compare melanin deposition from the entire dorsal part, the untreated left dorsal part and the treated right dorsal part were distinguished. The melanin deposition level was derived from the difference between the pigmented areas of the left dorsal skin and the right dorsal skin.

5) mRNA expression measurement by PCR

To identify how much influence $2 \% \mathrm{EF}+\mathrm{DW}$ and $2 \% \mathrm{EF}+\mathrm{PW}$ has to UVB irradiation for TRP-1, TRP-2(key enzymes of melanin synthesis) and MMP-9(key enzyme of aging) synthesis, the dorsal skin tissue was extracted from each HRM-2 mouse and mRNA level for each enzyme was measured through RQ PCR analysis.

(1) Total RNA extraction and cDNA synthesis

The dorsal skin tissue was extracted from each HRM-2 mouse, RNAzol ${ }^{\mathrm{B}}$ (500ul) was added, and was crushed with a homogenizer. Then $50 \mu \mathrm{ll}$ chloroform $\left(\mathrm{CHCl}_{3}\right)$ was added, and the mixture was blended for 15 seconds. It was left on ice for 15 minutes and centrifuged at $13,000 \mathrm{rpm}$. A supernatant of approximately 200ul was collected and mixed with 2-propanol (200ul), then shaken slowly and left for 15 minutes on ice. It was centrifuged at 13,000rpm again, washed with $80 \%$ $\mathrm{EtOH}$ and dried by vacuum pump for 3 minutes. Then RNA was extracted. The extracted RNA was

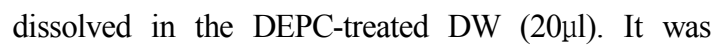
deactivated in the heating block at $75^{\circ} \mathrm{C}$ and was 
Table 4. Primed Sequences (in HRM-2 mice)

\begin{tabular}{|c|c|c|}
\hline Target gene & Primer & Sequences \\
\hline \multirow{2}{*}{ MMP-9 } & Forward & 5'-AATCTCTTCTAGAGACTGGGAAGGAG-3' \\
\hline & Reverse & 5'-AGCTGATTGACTAAAGTAGCTGGA-3' \\
\hline \multirow{2}{*}{ TRP-1 } & Forward & 5'-GCTGCAGGAGCCTTCTTTCTC-3' \\
\hline & Reverse & 5'-AAGACGCTGCACTGCTGGTCT-3' \\
\hline \multirow{2}{*}{ TRP-2 } & Forward & 5'-GGATGACCGTGAGCAATGGCC-3' \\
\hline & Reverse & 5'-CGGTTGTGACCAATGGGTGCC-3' \\
\hline GAPDH-VIC & Probe & 5'-CATGTTCCAGTATGACTCCACTCACG-3 \\
\hline
\end{tabular}

used in the first-strand cDNA synthesis.

(2) Reverse transcription

The total RNA (3ul) extracted from the dorsal skin tissue of the HRM-2 mouse was denaturized for 10 minutes at $75^{\circ} \mathrm{C}$. $2.5 \mu 110 \mathrm{mM}$ dNTPs mix, $1 \mu \mathrm{l}$ random sequence hexanucleotides $(25 \mathrm{pmol} / 25 \mu \mathrm{l}), 1 \mu \mathrm{l}$ RNase inhibitor $(20 \mathrm{U} / \mu \mathrm{l})$ as the RNA inhibitor, $1 \mu \mathrm{l}$ $100 \mathrm{mM}$ DTT, and $4.5 \mu \mathrm{l} 5 \times$ RT buffer $(250 \mathrm{mM}$ Tris- $\mathrm{HCl}, \mathrm{pH} 8.3,375 \mathrm{mM} \mathrm{KCl}, 15 \mathrm{mM} \mathrm{MgCl} 2)$ were added, and then $1 \mu \mathrm{l} \mathrm{M-MLV} \mathrm{RT} \mathrm{(200} \mathrm{U/ \mu l)} \mathrm{was}$ added to the mixture again to make the final volume

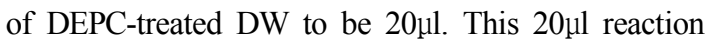
mixture solution was fully stirred and was centrifuged for 5 seconds at $2000 \mathrm{rpm}$. It was reacted for 60 minutes in the heating block at $37^{\circ} \mathrm{C}$ to synthesize the first-strand cDNA. It was left at 95 ${ }^{\circ} \mathrm{C}$ for 5 minutes to deactivate the M-MLVRT. Finally, the synthesized cDNA was used for PCR.

\section{(3) RQ PCR}

The Applied Biosystems 7500 Real-Time PCR system was used for RQ PCR, and the primer sequence used in the experiment is given in Table 4.

The SYBR Green primer for MMP-9, TRP-1, TRP-2 mRNA gene expression was analyzed with SYBR Green PCR MasterMix (ABI), and taqman probe for GAPDH (pn,4352339E, VIC dye-labelled, $\mathrm{ABI})$ were selected using Assays-on-Demand Gene Expression Products (ABI). Glyceraldehyde-3-phosphate dehydrogenase(GAPDH) (ABI) gene expression was used as an endogenous control.

For RQ PCR conditions, pre-denaturation was conducted for 2 minutes at $50^{\circ} \mathrm{C}$ and for 10 minutes at $94{ }^{\circ} \mathrm{C}$, and 40 cycles of denaturation were conducted for 15 seconds at $95^{\circ} \mathrm{C}$ and for 1 minute at $60^{\circ} \mathrm{C}$. GAPDH was used as the internal standard for the experimental group and the control group. The relative quantitative value of the target group was calculated by RQ PCR using the following equation: $y=x(1+e) n$, where $\mathrm{y}$ is the yield, $\mathrm{x}$ is the starting quantity, $\mathrm{n}$ is the number of cycles, and e denotes efficiency.

6) Histological observation of skins

To observe the optical microscopic change in the skin tissue, the extracted tissue was fixed in a $100 \%$ neutral formalin solution for 12 hours and washed with running water. It was hydrated with $70 \%, 80 \%$, $95 \%$, and $100 \%$ ethanol, and made transparent with xylene. After the penetration process, it was embedded with paraffin. The microtome was used to make the $4 \mu \mathrm{m}$-thick microsection from the produced paraffin block. Xylene was used to deparaffinize the microsection, which was then washed with salty water and tap water to dye it suitable for the purpose. To observe the general change of the skin tissue, it was placed in the Harris hematoxylin solution for 5 minutes to dye the nucleus. Then, it was washed with running water. It was deposited for three times with $1 \% \mathrm{HCl}$-alcohol solution and was 
fully washed. A $1 \%$ ammonium solution was used to color it blue, and it was moved to $80 \%$ alcohol. Next, 95\% alcohol and 100\% alcohol were used to dehydrate it. After it cleared, it was enclosed with Canadabalsam and then placed under the microscope for inspection.

\section{7) Statistical analysis}

The unpaired student $t$ test statistics was used to process each experimental group result, and significance was determined at levels not greater than $p<0.05\left({ }^{*} p<0.05,{ }^{* *} p<0.01,{ }^{* * *} p<0.001\right)$.

\section{Human skin safety test of EF added cosmetics}

To identify whether EF occurs skin inflammation, a patch test was implemented as a simple pre-test. Various types of cosmetics(toner, lotion and cream) containing EF kept at room temperature for 30 days were patched on soft underarm skin of 20 adults, sealed with Finn chamber on Scanpor tapes, and kept for 24 hours. The skin response was observed with naked eyes. The test was based on the method of Waggoner [13], Matsumura H [14], Aberer W [15], and the criteria was based on the international society of contact dermatitis as in Table 5 .

Table 5. The Expression Method of Patch Test

\begin{tabular}{cc}
\hline Reaction & Expression \\
\hline Negative & - \\
Imperfection erythema & \pm \\
Erythema & + \\
Small blister, Papule, Edema & ++ \\
Big blister, Necrosis & ++ \\
\hline
\end{tabular}

\section{Results}

\section{Effective HPLC component analysis on EF}

For behaviors of standard materials contained in EF contents, patterns of the standard material chlorogenic acid and isoquercitrin were identified with the pattern of EF respectively, by matching the retention times through HPLC with diode array detection. Among 70\% ethanol extracts of EF, the amount of chlorogenic acid was $4.52 \mathrm{mg} / \mathrm{g}$ (Fig. 1A), and isoquercitrin was $0.94 \mathrm{mg} / \mathrm{g}$ (Fig. 1B).

\section{Effect of EF on melanin synthesis in melanoma cell (in vitro)}

1) Cytotoxicity

Cytotoxicity of EF on the B16F10 cell was identified by MTT assay. High survival rate was shown in concentrations of $5,10,50,100,500 \mu$ $\mathrm{g} / \mathrm{ml}$, which were $104.2 \%, 98.6 \%, 95.8 \%, 95.7 \%$, $93.5 \%$ respectively. In the concentration of $1000 \mathrm{~g} / \mathrm{mL}$ the survival rate was $75.0 \%$ which is significantly reduced than the control group $(p<0.05)$. As the result, little cytotoxicity was exhibited from every concentration from $5 \mathrm{~g} / \mathrm{mL}$ to $500 \mathrm{~g} / \mathrm{mL}$. Therefore, for the whitening related signal transfer factor measurement in B16F10 cell, concentrations of high survival rate, $5 \mathrm{~g} / \mathrm{mL}, 25 \mathrm{~g} / \mathrm{mL}$, and $50 \mathrm{~g} / \mathrm{mL}$, were tested.

\section{2) Tyrosinase inhibitory activation}

As the result of tyrosinase activation inhibitory effect of EF, the concentrations of $500 \mathrm{~g} / \mathrm{mL}$ and $1000 \mathrm{~g} / \mathrm{mL}$ showed significant activation inhibition rate $(p<0.001)$. The activation inhibition rate was higher in higher EF concentration, and $1000 \mathrm{~g} / \mathrm{mL}$ showed the highest $50 \%$ activation inhibition (Fig. 2).

\section{3) TRP-1 mRNA gene expression}

TRP-1 mRNA gene expression was lower than the negative control group in every concentrations, and the gene expression decreased as EF concentration increased. In all concentrations, the TRP-1 mRNA 

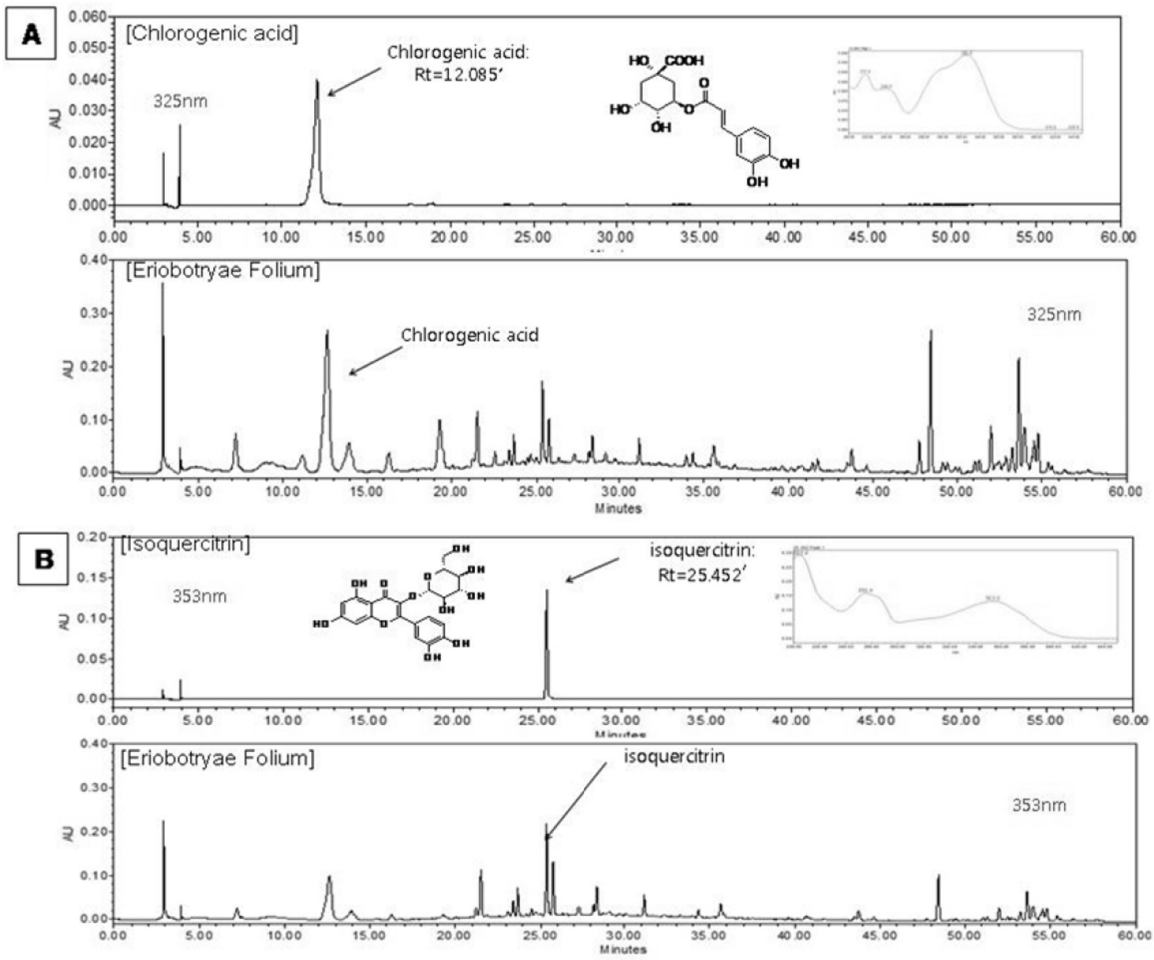

Fig. 1. HPLC chromatogram of standard chlorogenic acid, isoquercitrin and Eriobotryae Folium(EF)

(A) Chromatograms of standard chlorogenic acid and EF are recorded at $325 \mathrm{~nm}$.

(B) Chromatograms of standard isoquercitrin and EF are recorded at $353 \mathrm{~nm}$.

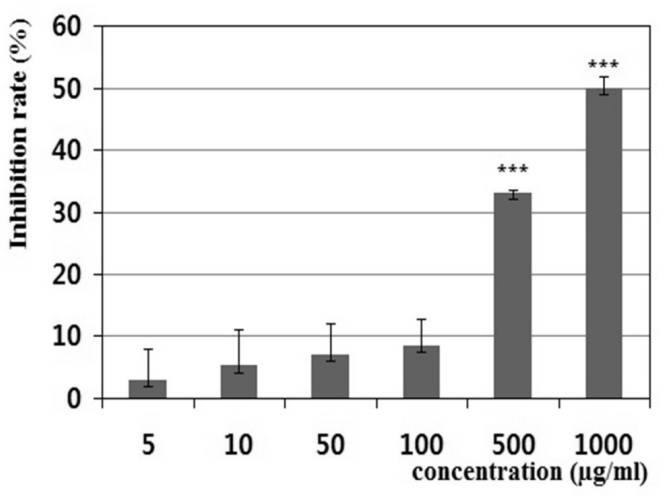

Fig. 2. Effect of Eriobotryae Folium on tyrosinase activation inhibition in B16F10 cell.

B16F10 cells were treated with various concentration of $\mathrm{EF}(5,10,50$, $100,500,1,000 \mu \mathrm{g} / \mathrm{m} \ell$ ). Then the cells were tested tyrosinase inhibitory activation.

The results represent the mean \pm S.D. of three individual experiments. Statistically significant value was calculated by Turkey's HSD test $\left({ }^{*} p<0.05,{ }^{* *} p<0.01,{ }^{* * *} p<0.001\right)$. gene expression was lower than the positive control group (Fig. 3A).

\section{4) TRP-2 mRNA gene expression}

TRP-2 mRNA gene expression was higher than the negative control group in every concentrations, and the gene expression decreased as EF concentration increased. The TRP-1 mRNA gene expression was higher than the positive control group in concentrations of $5 \mu \mathrm{g} / \mathrm{ml}$ and $25 \mu \mathrm{g} / \mathrm{ml}$, and was lower in the concentration of $50 \mu \mathrm{g} / \mathrm{ml}$ (Fig. 3B).

5) Tyrosinase mRNA gene expression

Whereas tyrosinase mRNA gene expression was significantly higher in $5 \mu \mathrm{g} / \mathrm{ml}$ concentration compared to the only a-MSH treated negative control group, it 

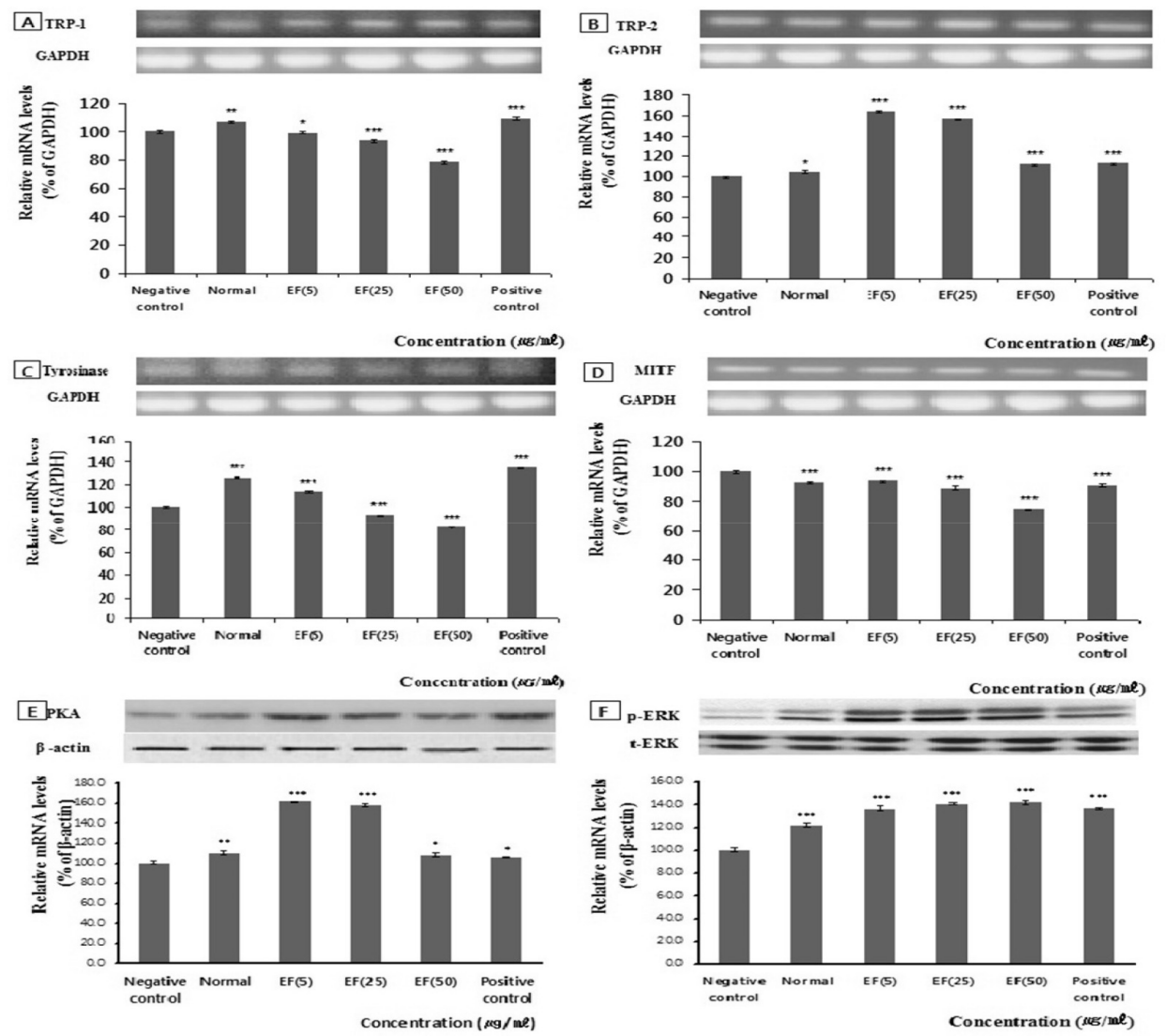

Fig. 3. Effect of Eriobotryae Folium on mRNA and PKA protein expression in B16F10 cell.

B16F10 cells were seeded on $100 \mathrm{~mm}$ culture dish. After 24 hours, cells were treated with $\alpha-\mathrm{MSH}, \mathrm{EF}(5,25,50 \mu \mathrm{g} / \mathrm{m} \ell)$ or kojic acid (50 ppm) for 24 hours. mRNA expression was analyzed with RT PCR and PKA protein expression was analyzed with Western blot.

The results represent the mean \pm S.D. of three individual experiments. Statistically significant value was calculated by comparing with negative control group using Turkey's HSD test $\left({ }^{*} p<0.05,{ }^{* *} p<0.01,{ }^{* * *} p<0.001\right)$.

Negative control : $\alpha-\mathrm{MSH}(100 \mathrm{nM})$ treatment

Normal : non treatment

Positive control : $\alpha-\mathrm{MSH}(100 \mathrm{nM})$ and kojic acid $(50 \mathrm{ppm})$ treatment

$\operatorname{EF}(5,25,50): \alpha-M S H(100 \mathrm{nM})$ and $\mathrm{EF}(5,25,50 \mu \mathrm{g} / \mathrm{ml})$ treatment.

(A) TRP-1 mRNA (B) TRP-2 mRNA (C) Tyrosinase mRNA

(D) MITF mRNA (E) PKA protein (F) ERK mRNA

was significantly lower in $25 \mu \mathrm{g} / \mathrm{ml}$ and $50 \mu \mathrm{g} / \mathrm{ml}$ concentrations $(p<0.001)$. The tyrosinase mRNA gene expression decreased as the EF concentration increased. Also, the gene expression was lower than the positive group in all concentrations (Fig. 3C).

6) MITF mRNA expression

MITF mRNA gene expression was significantly decreased in all concentrations compared to the only
a-MSH treated negative control group. As the concentration increased MITF mRNA gene expression decreased. Also, MITF mRNA gene expression was higher in $5 \mu \mathrm{g} / \mathrm{ml}$ concentration, and lower in $25 \mu$ $\mathrm{g} / \mathrm{ml}$ and $50 \mu \mathrm{g} / \mathrm{ml}$ concentrations compared to positive control group (Fig. 3D).

7) PKA protein expression

PKA protein expression was increased in $5 \mu \mathrm{g} / \mathrm{ml}$ 
and $25 \mu \mathrm{g} / \mathrm{ml}$ concentrations compared to the only a-MSH treated negative control group. As the concentration increased PKA protein expression decreased. Also, PKA protein expression was higher in all concentrations compared to the positive control group (Fig. 3E).

\section{8) ERK mRNA expression}

ERK mRNA gene expression was increased in every concentration compared to the only a-MSH treated negative control group $(p<0.001)$. As the concentration increased ERK mRNA gene expression also increased. Also, ERK mRNA gene expression was lower than the positive control group in $5 \mu \mathrm{g} / \mathrm{ml}$ concentration, and was higher in $25 \mu \mathrm{g} / \mathrm{ml}$ and $50 \mu$ $\mathrm{g} / \mathrm{ml}$ concentration (Fig. 3F).

\section{Effect of EF with PW on melanin synthesis in HRM-2 melanin-possessing hairless mice (in vivo)}

1) Image analysis software

Melanin difference between the untreated left dorsal skin and the specimen applied right dorsal skin was like the following (Fig. 4, Table 6).

On the first week the experimental groups 1 and 2 were higher but not significantly different from the negative control group.

On the third week the experimental groups 1 and 2 were significantly higher from the negative control group $(p<0.001)$. The experimental group 1 wa $\mathrm{s}$

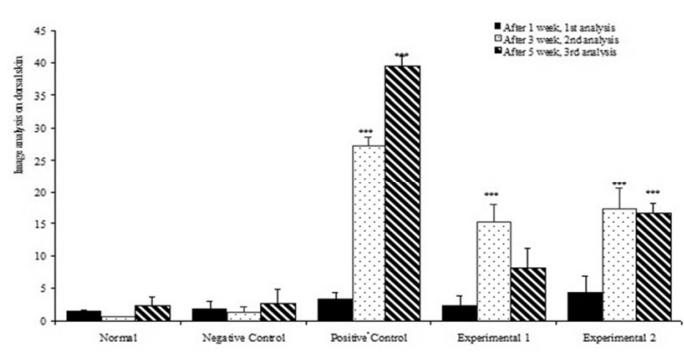

Fig. 4. Effect of Eriobotryae Folium\& phreatic water on pigmentation in dorsal skin of HRM-2 mice exposed to UVB.

Five weeks after the initiation of UVB irradiation (the stage of hyperpigmentation) Dorsal skin left part and right part photograph image analysis. The dorsal skin whitening values showing brightness of skin color were measured using image analysis software (each system ships with one full version of Quantity One and unlimited copies of Quantity One Basic Mode.).

The results represent the mean \pm S.E. $(n=6)$. Statistically significant value was calculated by comparing with negative control group using student $\mathrm{t}$ test $\left(* p<0.05,{ }^{* *} p<0.01,{ }^{* * *} p<0.001\right)$.

Normal : base ointment application

Negative control : UVB irradiation and base ointment application

Positive control : UVB irradiation and $0.5 \%$ sunblock cream application

Experimental 1 : UVB irradiation and 2\% EF + DW cream application Experimental 2 : UVB irradiation and $2 \% \mathrm{EF}+\mathrm{PW}$ cream application

12.1 times higher than the negative control group, and the experimental group 2 was 13.8 times higher. On the contrary, the melanin difference of the positive control group was 21.5 times higher than negative control group, which is higher than the experimental groups 1 and 2.

On the fifth week, the melanin difference of the experimental group 2 was 6.4 higher than the negative control group, which is significant $(p<0.001)$.

The experimental group 1 was 3.1 times higher than

Table 6. Melanin Difference between Untreated Part(left) and Treated Part(right)

\begin{tabular}{cccc}
\hline Group & $1^{\text {st }}$ week & $3^{\text {rd }}$ week & $5^{\text {th }}$ week \\
\hline Normal & $1.51 \pm 0.16$ & $0.63 \pm 0.07$ & $2.26 \pm 1.40$ \\
Negative control & $1.87 \pm 1.09$ & $1.27 \pm 0.98$ & $2.64 \pm 2.29$ \\
Positive control & $3.39 \pm 1.00$ & $27.35 \pm 1.28$ & $39.45 \pm 1.61$ \\
Experimental 1 & $2.27 \pm 1.54$ & $15.35 \pm 2.78$ & $8.17 \pm 3.06$ \\
Experimental 2 & $4.31 \pm 2.60$ & $17.49 \pm 3.20$ & $16.80 \pm 1.47$ \\
\hline
\end{tabular}

Normal : base ointment application; Negative control : UVB irradiation and base ointment application; Positive control : UVB irradiation and $0.5 \%$ sunblock cream application; Experimental 1 : UVB irradiation and 2\% EF + DW cream application; Experimental 2 : UVB irradiation and $2 \% E F+P W$ cream application. 

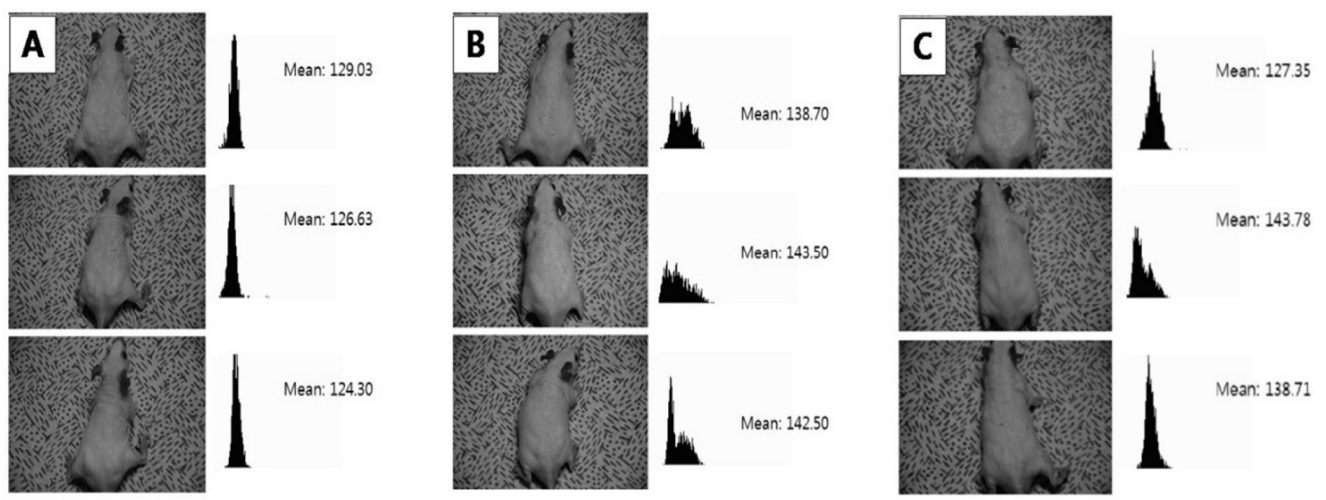

Fig. 5. Image analysis of negative control group

Image analysis of treated part(right, only base ointment application) compared to untreated part(left) after UVB irradiation. Mean means peak area of a half dorsal skin calculated using image analysis software $(n=6)$.

(A) After 1 week UVB irradiation (B) After 3 weeks UVB irradiation (C) After 5 weeks UVB irradiation

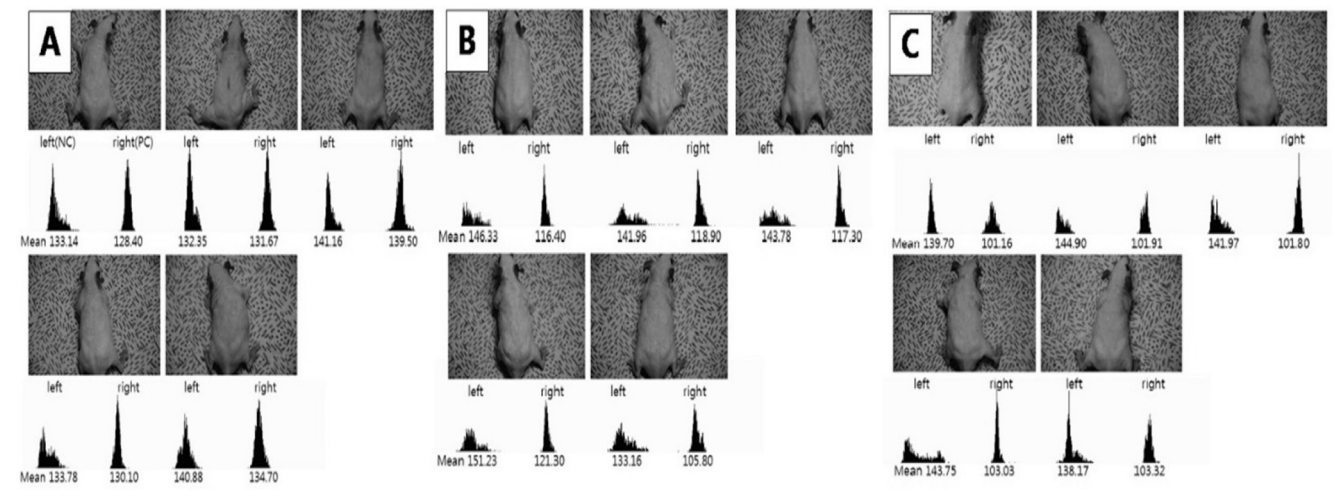

Fig. 6. Image analysis of positive control group

Image analysis of treated part(right, $0.5 \%$ sunblock cream application) compared to untreated part(left) after UVB irradiation. Mean means peak area of a half dorsal skin calculated using image analysis software $(n=6)$.

(A) After 1 week UVB irradiation (B) After 3 weeks UVB irradiation (C) After 5 weeks UVB irradiation

negative control group, but it was not significant. On the contrary, the positive control group was 14.9 times higher than negative control group, and it was higher than experimental groups 1 and 2 .

The experimental group 2 was 1.9 times higher on the first week, 1.1 times higher on the second week, and 2.1 times higher on the fifth week compared to the experimental group 1.

2) RQ PCR analysis

(1) TRP-1 mRNA expression
TRP-1 mRNA gene expression of the experimental group 1 was significantly lower than the negative control group by $26.64 \%(p<0.05)$, and that of the experimental group 2 was lower than the negative control group by $30.99 \% \quad(p<0.01)$. On the other hand, the positive control group was significantly lower than the negative control group by $42.90 \%$ $(p<0.01)$. Also, TRP-1 mRNA gene expression of the experimental group 2 was about $5.93 \%$ lower than the experimental group 1(Fig. 8A). 

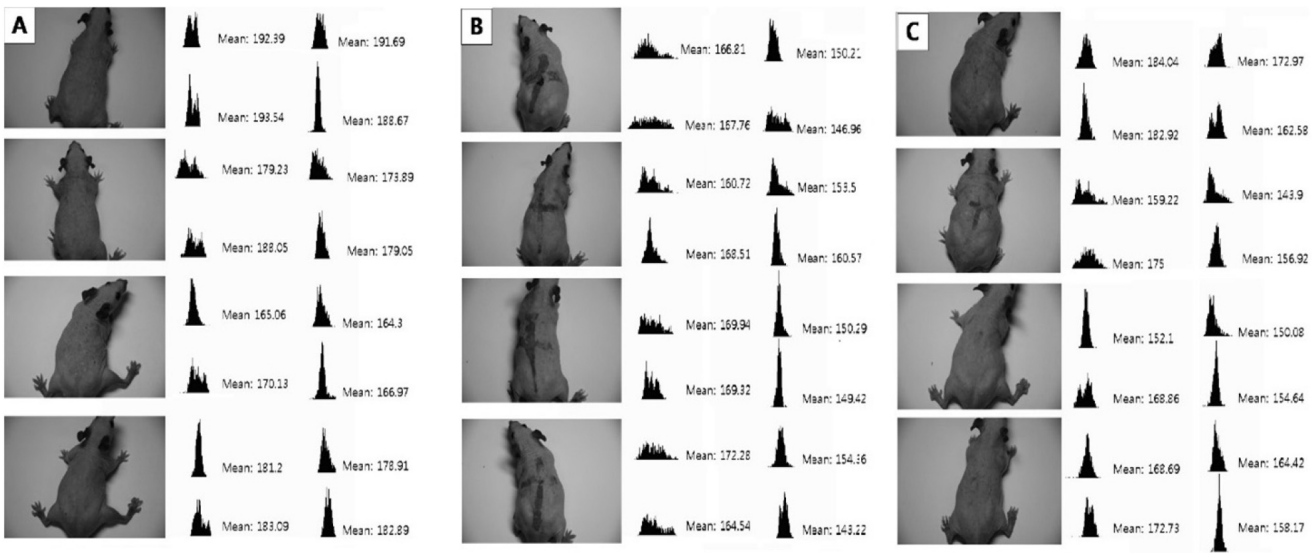

Fig. 7. Image analysis of experimental group

Image analysis of treated part (upper right, $2 \% \mathrm{EF}+\mathrm{DW}$ cream application; lower right, $2 \% \mathrm{EF}+\mathrm{PW}$ cream application) compared to untreated part(left) after UVB irradiation. Mean means peak area of a quarter dorsal skin calculated using image analysis software $(n=6)$.

(A) After 1 week UVB irradiation (B) After 3 weeks UVB irradiation (C) After 5 weeks UVB irradiation
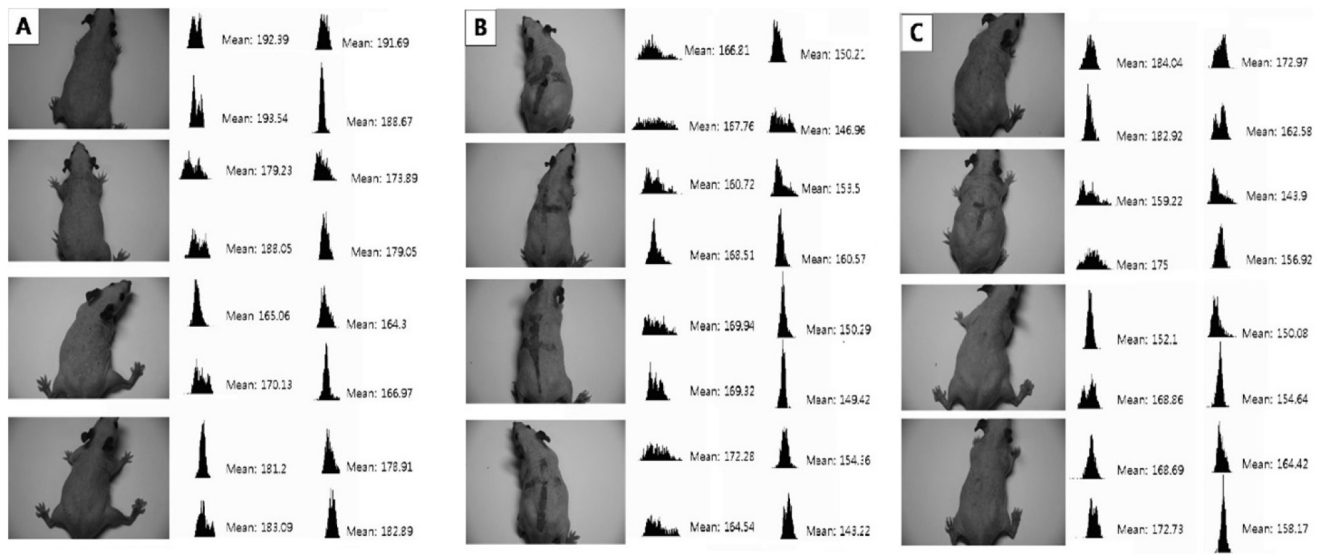

Fig. 8. Effect of Eriobotryae Folium \& phreatic water on mRNA expressions in dorsal skin of HRM-2 mice.

HRM-2 mice were sacrificed, and mRNA expression were checked in dorsal skin. mRNA expressions were analyzed with RQ PCR. The results represent the mean $\pm S . E(n=6)$. Statistically significant value was calculated by comparing with negative control group using Student $t$ test $\left({ }^{*} p<0.05,{ }^{* *} p<0.01\right)$.

Normal : base ointment application

Negative control : UVB irradiation and base ointment application

Positive control : UVB irradiation and $0.5 \%$ sunblock cream application

Experimental 1 : UVB irradiation and $2 \% \mathrm{EF}+\mathrm{DW}$ cream application

Experimental 2 : UVB irradiation and2\% EF + PW cream application

(A) TRP-1 mRNA expression (B) TRP-2 mRNA expression (C) MMP-9 mRNA expression

(2) TRP-2 mRNA gene expression

TRP-2 mRNA gene expression of the experimental group 1 was $13.27 \%$ lower than the negative control group, and the experimental group 2 was $13.16 \%$ lower than the negative control group, both of which are not significant. On the other hand, the positive control group was significantly lower than the negative control group by $28.37 \% \quad(p<0.01)$. Also, TRP-2 mRNA gene of the experimental group 1 and 2 were similar by 0.804 and 0.805 respectively (Fig. 8B). 
(3) MMP-9 mRNA gene expression

MMP-9 mRNA gene expression of the experimental group 1 was $24.75 \%$ lower than the negative control group, and the experimental group 2 was $36.18 \%$ lower than the negative control group, both of which are not significant. On the other hand, the positive control group was significantly lower than the negative control group by $65.40 \%(p<0.01)$. Also, MMP-9 mRNA gene expression of the experimental group 2 was lower than the experimental group 1 by $15.20 \%$ (Fig. 8 C).

\section{3) Histological analysis}

After the experiment, the dorsal skin of the HRM-2 mouse was extracted and dyed with hematoxylin and eosin to assess whether EF and PW can inhibit the damage of UVB irradiated dorsal tissue. The analysis showed that the epidermis of the negative control group was excessively formed and expanded, and hyperkeratinization, pigmentation, granulation, and parakeratosis infiltration was observed, which indicates tissue damage by UVB irradiation. The epidermis of the positive control group, experimental group 1, and experimental group 2 was thinner close to the normal group, and the pigmentation, cell transformation, keratinization, and infiltration were also similar to the normal group. Especially in case of the $\mathrm{EF}+\mathrm{PW}$ used experimental group 2, the epidermis was thinner closer to the normal group compared to the only EF used experimental group 1(Fig. 9).

\section{Human skin safety test of EF added cosmetics}

To identify whether EF occurs skin inflammation, a patch test was implemented as a simple pre-test. As the result, negative reaction occurred in all 20 subjects (Fig. 10).

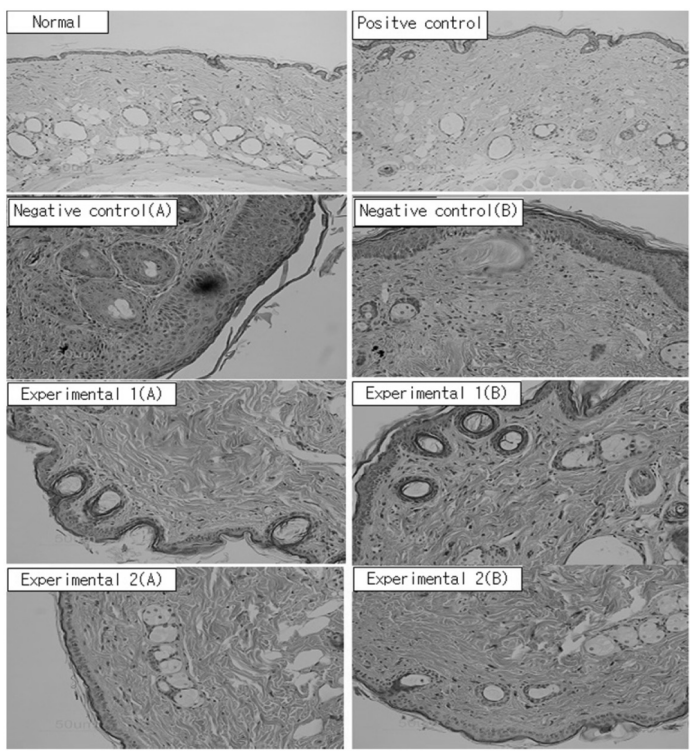

Fig. 9. Histological analysis of HRM-2 mice dorsal skin. HRM-2 micewere sacrificed, and dorsal skin were processed for histology and stained with hematoxylin and eosin. It shows the thickening of epidermis by bright microscope.

We removed $\mathrm{HRM}-2$ mice dorsal skin and analyzed with hematoxylin and eosin staining. The results were evaluated the degree of epidermal thickening, hyperpigmentation and histopathological changes in skin tissues. We observed skin tissues through an optical microscope.

Normal : base ointment application

Negative control : UVB irradiation and base ointment application Positive control : UVB irradiation and $0.5 \%$ sunblock cream application

Experimental 1 : UVB irradiation and 2\% EF + DW cream application Experimental 2 : UVB irradiation and $2 \% \mathrm{EF}+\mathrm{PW}$ cream application

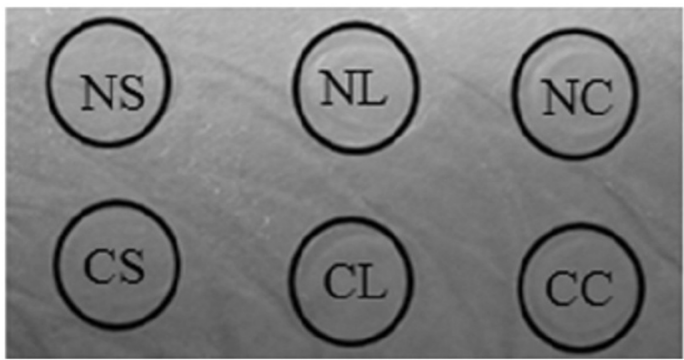

Fig. 10. The patch test photograph of the cosmetics containing Eriobotryae Folium extracts.

NS : Toner not contaning Eriobotryae Folium extracts

$\mathrm{NL}$ : Lotion not contaning Eriobotryae Folium extracts

NC : Cream not contaning Eriobotryae Folium extracts

CS : Toner contaning Eriobotryae Folium extracts

$\mathrm{CL}$ : Lotion contaning Eriobotryae Folium extracts

CC : Cream contaning Eriobotryae Folium extracts 


\section{Discussion}

Melanin plays the most important role in determining skin color. It is synthesized by melanosome of melanocyte existing in epidermis, and moves to keratinocyte through dendrite to create color [16].

The primary role of melanin is to eliminate active oxygen in skin, and block ultraviolet ray (Compilation Committee of Dermatology Textbooks., 2001). However, excessive pigmentation of melanin can cause negative effects such as freckles, skin aging, skin cancer, and cell death [16]. Melanin synthesis starts by tyrosine hydroxylase activation which converts tyrosine into DOPA by tyrosinase, and by DOPA oxidase activation which oxidizes DOPA into DOPA quinone [17]. Melanosome contains enzymes that generate normal melanine. Tyrosinase, tyrosinase-related protein 1 (TRP-1), tyrosinase-related protein 2 (TRP-2) are the well-known enzymes [18,19,20].

In the intracellular signal pathways, when melanin cells are activated and melanin synthesis proceeds, activation of adenylate cyclase increases, and cAMP density increases.

Protein kinase A (PKA) is cAMP dependent protein kinase which controls various enzyme activation, and it is related to cellular multiplication [21]. So the activation of PKA induces tyrosinase phosphorylation. When PKA expression is inhibited, melanin synthesis is inhibited through the blockage of tyrosinase activation. Also, MITF is an important transcription control factor in the melanin synthesis process, which moves to nucleus and increases DNA activation of tyrosinase, TRP-1 and TRP-2 and promotes melanin synthesis. Therefore, inhibition of MITF can inhibit the expression of tyrosinase, TRP-1 and TRP-2, which eventually inhibits melanin synthesis [22].

Extracellular regulated kinase (ERK) is the intracellular signal transfer protein and is known as a factor that controls gene expression [23]. Recent studies show that the activation of ERK pathway suppresses melanin synthesis as MITF decreases through ubiquitination [24]. Thus, when ERK expresseion increases, melanin synthesis may be inhibited. An effective and stable whitening material should inhibit the signal pathways and the gene expression of enzymes involved in melanin synthesis. The melanin inhibition effect of the whitening materials can be judged by evaluating their effects on tyrosinase, TRP-1, TRP-2, MITF, PKA, and ERK.

In this research, in vitro and in vivo experiments were conducted to evaluate the whitening effect of a natural material EF, which has been widely used for various skin diseases. In the animal experiment using HRM-2 melanin-possessing hairless mice, phreatic water (PW), long known to be effective to skin enhancement, was used to assess whether the effect can be increased when combined with EF. Also, a patch test was conducted as a pre-test to confirm safety for the future clinical experiments.

As the result of HPLC analysis, the volume of the index ingredient chlorogenic acid was $4.52 \mathrm{mg} / \mathrm{g}$ and isoquercitrin was $0.94 \mathrm{mg} / \mathrm{g}$ among $70 \% \mathrm{EF}$ ethanol extracts(Fig. 1).

Chlorogenic acid is 3-(3, 4-dihydroxycinnamoyl) quinate, which is the ester of caffeic acid and (L)-quinic acid. It is known to be widely distributed in crude drugs or foods such as coffee, and is a natural organic compound that is synthesized in vivo. It has fewer side effects and has anti-virus, anti-bacteria, and anti-fungal effects. Its blood glucose and blood pressure regulatory effects are also known [25]. The study of Im [26] found out that acanthopanax extract has the melanin inhibitory effect by reducing the amount of tyrosinase and TRP-2 expressions in melanoma cells, and chlorogenic acid and caffeic acid were suggested as the effective ingredients. Therefore, chlorgenic acid in EF is considered to be playing an important role in the whitening effect by suppressing major enzymes and signaling pathways related to melanin 
synthesis.

Isoquercitrin is the glycoside of quercetin, a type of polyphenol, and is known to have various medical effects such as antioxidant, anti-inflammation, anti-allergy, anti-cancer, hypertension and hyperlipidemia inhibition effects [27]. In the research of Jo [28], it was proved that isoquercitrin has an excellent cell protective effect by increasing the survival rate of the oxidative damage induced $\mathrm{HaCaT}$ cells, and the feasibility of isoquercitrin to skin aging by active oxygen was suggested. In this research, it was found that EF breaks down proteins such as collagen and reduces the expression of MMP-9 mRNA which fosters aging. This is assumed to be related to cell protective effect, and additional studies seem to be necessary in the future.

From the in vitro experiment using B16F10 cells, it was found that EF inhibits tyrosinase activation and TRP-1 mRNA, tyrosinase mRNA, MITF mRNA expressions, and the extract also inhibits melanin synthesis by promoting ERK mRNA expression; this suggests the whitening effect of EF. All of the results were statistically significant, and it was more effective than the positive control group kojic acid. Despite the fact that the inhibitory effect of EF on TRP-2 mRNA and PKA protein expression was smaller than the negative control group, the expression tended to be reducing dependently as the EF concentration increased. Additional research on this seemes to be necessary in the future.

The image analysis software from in vivo experiment using HRM-2 melanin-possessing hairless mice showed that $\mathrm{EF}+\mathrm{PW}$ had an excellent inhibitory effect on melanin synthesis. Larger melanin difference between the untreated left dorsal skin and the specimen applied right dorsal skin means that the specimen has higher melanin synthesis inhibitory effect. The experimental groups 1 and 2, which are applied with EF cream, had more inhibitory effect than the negative control groups. Also, the experimental group 2, applied with EF +
PW cream, had higher inhibitory effect than the experimental group 1, applied with $\mathrm{EF}+\mathrm{DW}$ cream, which means that PW enlarges the whitening effect when combined with EF. However, the inhibitory effect did not reach the positive control group applied with $0.5 \%$ sunblock cream, leaving more experiments to be continued along the effort to enlarge the whitening effect of EF.

According to the RQ PCR analysis of mRNA expressions on HRM-2 mice dorsal skins, EF had the whitening effect by inhibiting melanin synthesis by suppressing TRP-1, TRP-2 mRNA expressions, and the effect was enlarged when used with PW. EF inhibited TRP-1 mRNA expression more significantly, which was consistent with the previous in vivo experiment in which EF inhibited TRP-1 better than TRP-2. MMP-9 is a zinc-dependent protease which breaks down extracellular matrix. When the activation increases proteins such as collagen in skin collapse, and forms wrinkles that progress aging [29]. It is expected that EF would block skin aging by inhibiting MMP-9 mRNA expression, along with the whitening effect through melanin control. The effect would also be enlarged when used with PW. Histological analysis of HRM-2 mice dorsal skin showed that EF and PW visually inhibited melanin synthesis on skin surface and the enzymes involved, and they also act as the skin protectants from extreme pigmentation and aging, histologically.

Put together the above in vivo experiment using HRM-2 melanin-possessing hairless mice, EF inhibited melanin synthesis on UVB iradiated dorsal skins, it suppressed gene expression related to melanin and skin aging, and the result was observed histologically. Also, the effects were enhanced when PW was combined.

A patch test was conducted as a pre-test to for further clinical experiments, and the result showed negative response on all 20 male and female adult subjects, which indicates low possibility of problems such as inflammation. However, further researches 
are necessary before clinical commercialization of $\mathrm{EF}$ based products.

Above researches showed various mechanisms and effects of EF inhibiting melanin synthesis. Also, the effect was enlarged when EF was combined with PW. Therefore, EF and PW are expected to be actively used in further researches on development of natural whitening materials based on this paper.

However, the number of objects in this research were limited, so continuous studies are necessary. Clinical experiments on human bodies are also required as well as animal experiments. According to Seo's research [30], EF contains a toxic component amygdalin, so there is a possibility to various side effects. The dosage and hair removal is also required in order to prevent poisoning. In order for EF to be used widely, additional studies on side effects are necessary.

If further systematic researches on finding the exact mechanisms of melanin inhibition effect of $\mathrm{EF}$ and the development of various forms of the materials are continued, natural cosmetics and medicines for whitening and treating pigmentation would be able to be developed.

\section{Conclusion}

1. According to the HPLC analysis, the amount of chlorogenic acid was $4.52 \mathrm{mg} / \mathrm{g}$, and isoquercitrin was $0.94 \mathrm{mg} / \mathrm{g}$ among $70 \%$ ethanol extracts of $\mathrm{EF}$.

2. From the in vitro experiment using B16F10 cells, it was found that $\mathrm{EF}$ inhibits tyrosinase activation and TRP-1 mRNA, tyrosinase mRNA, MITF mRNA expressions, and the extract also inhibits melanin synthesis by promoting ERK mRNA expression; this suggests the whitening effect of EF. All of the results were statistically significant.

3. From the in vivo experiment using HRM-2 melanin-possessing hairless mice, the melanin difference between group 1 and 2 was significant on the third and fifth week of UVB irradiation.
RQ PCR analysis showed that TRP-1 mRNA expression of group 1 and 2 was significantly inhibited, and TRP-2 mRNA, MMP-9 mRNA expressions were also inhibited but not significantly. In the histological analysis, EF extracts prevented skin damages such as thickness of the epidermis, hyperpigmentation in the peripheral cells, cell mutation, keratinization, and infiltration. In all of the above in vivo experiments, the experimental group 2 showed better melanin synthesis and tissue damage inhibitory effects than the experimental group 1 .

4. The patch test showed negative reactions in all 20 adult subjects.

\section{Abbreviations}

EF: Eriobotryae Folium DW: distilled water

PW: phreatic water

HPLC: high performance liquid chromatography

RT PCR: reverse transcription polymerase chain reaction

RQ PCR: real time quantitative polymerase chain reaction

TRP-1: tyrosinase related protein-1 TRP-2: tyrosinase related protein-2

PKA: protein kinase A

MITF: microphthalmia-associated transcription factor

ERK: extracellular regulated kinase MMP-9: matrix metalloproteinase-9.

\section{Declarations}

\section{Ethics approval and consent to participate}

This experiment was approved by the Institutional Animal Care and Use Committee of Daejeon University (approval number: DJUARB2012-019) for ethical and scientific validity of animal experiment and efficient management. 


\section{Consent for publication}

Not applicable

\section{Avaliability of data and material}

Data supporting our findings are contained within the manuscript.

\section{Competing interest}

The authors declare that they have no competing interests.

\section{Funding}

This research was supported by the Daejeon University fund(2013)

\section{Authors' contributions}

T.W.A. have been involved in conducting the research. J.H.P collected the background data, and T.W.A wrote the first draft of the manuscript. All authors participated in the revision of subsequent drafts, and all approved the final version of the manuscript.

\section{Acknowledgements}

This research was supported by the Daejeon University Research Grants (2016).

\section{Reference}

1. Do EJ, Lee JS, Park HJ, Ha ID, Kim YC, Kim MR. The Efficacy of Ampule Containing Herbal Extract for Improving Skin Wrinkles in Women. The Korean Journal of Oriental Medical Prescription. 2009;17(2):111-121.

2. Lim SJ. Skin-Whitening Awareness and Whitening -Care Behavior in Women. Jounal of The Korean Society of cosmetology. 2009;15(2): 463-474

3. Prota G. Melanins and Melanogenesis. Academic
Press. 1992;208-209.

4. Lee HH. Current Trends on the Development of Whitening Products. Journal of the society of cosmetic scientists of Korea. 1997;23(1):43-56.

5. Yeo MG. Compilation Committee of Dermatology Textbooks. Dermatology. Seoul:2001:1-9, 133, 409-12, 553-555.

6. Kim SH, Jung H, Shin YC, Ko SG. Research of Traditional Herbal Medicines for Anti-aging, Inhibition Effect of Wrinkle and Whitening Effect in the Skin. Korean J. Oriental Physiology \& Pathology. 2008;22(3):691-698.

7. Kim SJ, Park J, Park SN. Antioxidative Effect and Component Analysis of Eriobotrya japonica Leaf Extracts. Journal of the society of cosmetic scientists of Korea. 2012;38(1):57-65.

8. Jang MH, Go GY, Ahn YC, Ahn TW. Effect of DOGO phreatic water containing sulphur on Atopic Dermatitis in NC/Nga mouse. The Journal of Korean Medical Ophthalmology \& Otolaryngology \& Dermatology. 2013;26(3):36-53.

9. Carmichael J, DeGraff WG, Gazdar AF, Minna JD, Mitchell JB. Evaluation of a tetrazolium based semiautomated colorimetric assay: assessment of chemosensitivity testing. Cancer Res. 1987;(47): 936-942.

10. Yagi A, Kanbara T, Morinobu N. The effect of tyrosinase inhibition for aloe. Planta Medica. 1986:517-519.

11. Furuya RK, Akiu S, Ideta RR, Naganuma MK, Fukuda MR, Hirobe TH. Changes in the Proliferative Activity of Epidermal Melanocytes in Serum-Free Primary Culture During the Development of Ultraviolet Radiation B-Induced Pigmented Spots in Hairless Mice. Pigment Cell Res. 2002;(15):348-356.

12. Kimura YU, Sumiyoshi MH. French Maritime Pine Bark (Pinus maritima Lam) Extract (Flavangenol) Prevents Chronic UVB Radiation-induced Skin Damage and Carcinogenesis in Melanin-possessing Hairless Mice. Photochemistry and Photobiology. 
2010;86:955-963.

13. William $\mathrm{C}$ W. Clinical safety and efficacy testing of cosmetics. Cosmetic Science and Technology Series. 1990;8:105

14. Matsumura H, Oka K, Umekage K, Akita H, Kawal J, Kitazawa Y, et al. Effect of occlusion on human skin. Contact Dermatitis. 1995;33(4): 231-235.

15. Aberer W, Andersen KE, White IR. Should patch testing be restricted to dermatologists only?. Contact Dermatitis. 1993;28(1):1-2.

16. Kameyama K, Takemura T, Hamada Y, Sakai C, Kondoh S, Nishiyama S. Pigment production in murine melanoma cells is regulated by tyrosinase. tyrosinase-related protein 1(TRP 1) dopachrome tautomerase(TRP 2) and a melanogenic inhibitor. J Invest Dermatol. 1993;100:126.

17. Alvaro SF, Jose Neptuno RL, Francisco GC. Tyrosinase a comprehensive review of its mechanism. Biochim Biophys Acta. 1995;1247:1-11.

18. Jimbow $\mathrm{K}$, Alena $\mathrm{F}$, Dixon $\mathrm{W}$, Hara $\mathrm{H}$. Regulatory factors of pheomelanogenesis and eumelanogenesis in melanogenic compartments. Pigment Cell Res. 1992;2:36-42.

19. Boissy RE, Sakai C, Zhao H, Kobayashi T, Hearing VJ. Human tyrosinase related protein-1 (TRP-1) dose not function as a DHICA oxidase activity in contrast to murine TRP-1. Expp Dermatol. 1998;7(4):198-204.

20. Tsukamoto K, Jackson IJ, Urabe K, Montague PM, Hearing VJ. A second tyrosinase-related protein, TRP-2, is a melanogenic enzyme termed DOPAchrome tautomerase. EMBO J. 1992;11(2): 519-26.

21. Lee J, Kim YS, Park D. Rosmarinic acid induces melanogenesis through protein kinase A activation signaling. Biochem Pharmacol. 2007; 74(7):960-968.

22. Jimenez-Cervantes $C$, Martinez-Esparza $M$, Perez C, Daum N, Solano F, Garcia-Borron JC. Inhibition of melanogenesis in response to oxidative stress: transient down regulation of melanocyte differentiation makers and possible involvement of microphthalmia transcription factor. Journal of cell science . 2004;114(12): 2335-2344.

23. Huang SC, Ho CT, Lin-Shiau SY, Lin JK. Carnosol inhibits the invasion of B16/F10 mouse melanoma cells by suppressing metalloproteinase- 9 through down-regulating nuclear factor-kappa B and c-Jun. Biochemical pharmacology. 2005; 69(2):221-232.

24. Kim DS, Hwang ES, Lee JE, Kim SY, Kwon SB, Park KC. Sphingosine-1-phosphate decreases melanin synthesis via sustained ERK activation and subsequent MITF degradation. Journal of cell science. 2003;116(9):1669-1706.

25. Kim SH. Pharmacokinetics and Hepatic Uptake of Chlorogenic Acid and Caffeic Acid[Master's thesis]. Cheongju:Chungbuk National University; 2012

26. Im KR, Kim MJ, Jung TK, Yoon KS. The Inhibitory Effects of Acanthopanax sessiliflorum Seeman on Melanogenesis. Journal of the society of cosmetic scientists of Korea. 2008;34(2): 149-156.

27. Lee SB, Chung DW. RESEARCH PAPERS : Study on the Synthesis of Isoquercitrin by Enzymatic Partial Hydrolysis. Applied Chemistry for Engineering. 2014;25(2):152-156.

28. Jo NR, Gu HA, Park SA, Han SB, Park SN. Cellular Protective Effect and Liposome Formulation for Enhanced Transdermal Delivery of Isoquercitrin. J. Soc. Cosmet. Scientists Korea. 2012;38(2):103-118.

29. Nagase H, Visse R, Murphy G. Structure and fuction of matrix metalloproteinases and TIMPs. Cardiovasc Res. 2006;69:562-73.

30. Seo BI. A philological study on poisoning and side effects of Eriobotryae Folium. The Journal of Jaehan Oriental Medical Academy. 2012; 10(2):65-68. 